\title{
GEOTOURIST POTENTIAL OF ROCK GEOMORPHOSITES AS INTEGRAL PART OF GEO-KARPATY UKRAINIAN-POLISH GEOTOURISTIC ROUTE
}

\author{
Yuri Zinko ${ }^{1}$, Martha Malska ${ }^{1}$, Ihor Bubniak ${ }^{2}$, Roman Hnatyuk ${ }^{1}$, \\ Leonid Skakun ${ }^{1}$, Andrzej Solecki ${ }^{3}$ \\ ${ }^{1}$ Ivan Franko National University of Lviv, 41 Doroshenko street, Lviv, Ukraine, \\ 79000,e-mail: zinkoyuriy@gmail.com \\ ${ }^{2}$ Lviv Polytechnic National University, 12 Bandera street, Lviv, Ukraine, 79013 \\ ${ }^{3}$ Wroclaw University, plac Uniwersytecki 1, 50-137 Wrockaw, Poland
}

In 2013-2015 within the frames of Cross-border Cooperation Programme Poland-BelarusUkraine a project to develop the Geo-Karpaty (Geo-Carpathians) cross-border tourist route in the Ukrainian and Polish Carpathians was implemented. The route length is $700 \mathrm{~km}$ and it includes 28 geo-tourist sites. Its attractive base consists of scientifically, educationally, scenically and aesthetically valuable geological outcrops, relief forms and manifestations of modern dynamic processes. The majority of objects located along the Ukrainian-Polish geotourist route is presented by geomorphosites, i.e. objects of geomorphological heritage (rocks, river valleys, anthropogenic forms, geomorphological processes).

In the present study the geotourist analysis of Geo-Karpaty route specific rock complexes is performed: Rocks of the Kamieniec Castle in Odrzykon, rocks in the Przadki Reserve, Kamień Leski (Baszta Kmity) from the Polish side, Spaskyi (Sokoliv) Stone, the Urych Rocks, the Dovbush Rocks from the Ukrainian side. It includes a detailed description of geological structure and morphological features, historical and cultural assessment, modern tourist-aimed usage and infrastructure facilities. Solutions on preservation and protection of the Geo-Karpaty route rock geomorphosites and their utilization in educational tourism are given.

Key words: geotourism, route, Geo-Karpaty, rock geotourist objects, geomorphosites, infrastructure.

Introduction. The problem of geo-tourism development in the Carpathians has become topical over the course of the last decade. One of the projects related to geotourism in the Ukrainian and Polish Carpathians implemented in 2013-2015 was the development of international Geo-Karpaty tourist route under the Cross-border Cooperation Programme Poland-Belarus-Ukraine. The working team included educational establishments from Ukraine and Poland, i.e. Higher Technical School in Krosno (Podkarpackie Voivodeship) and Ivan Franko National University of Lviv. Within the project scope the concept was elaborated and the cross-border route over $700 \mathrm{~km}$ long was arranged (Fig. 1).

Geo-tourist route runs through the mountain massifs in Krosno and Przemysl subregions (Podkarpackie Voivodeship) in Poland and through Lviv and Ivano-Frankivsk regions in Ukraine. Along the geo-tourist route 28 information boards describing the most important geo-tourist attractions are placed [3].

Among the objects being a part of the mentioned geo-tourist route there are several ones having all the features of geomorphosites - objects of geomorphological heritage.

(C) Zinko Y, Malska M., Bubniak I., Hnatyuk R., Skakun L., Solecki A., 2017 


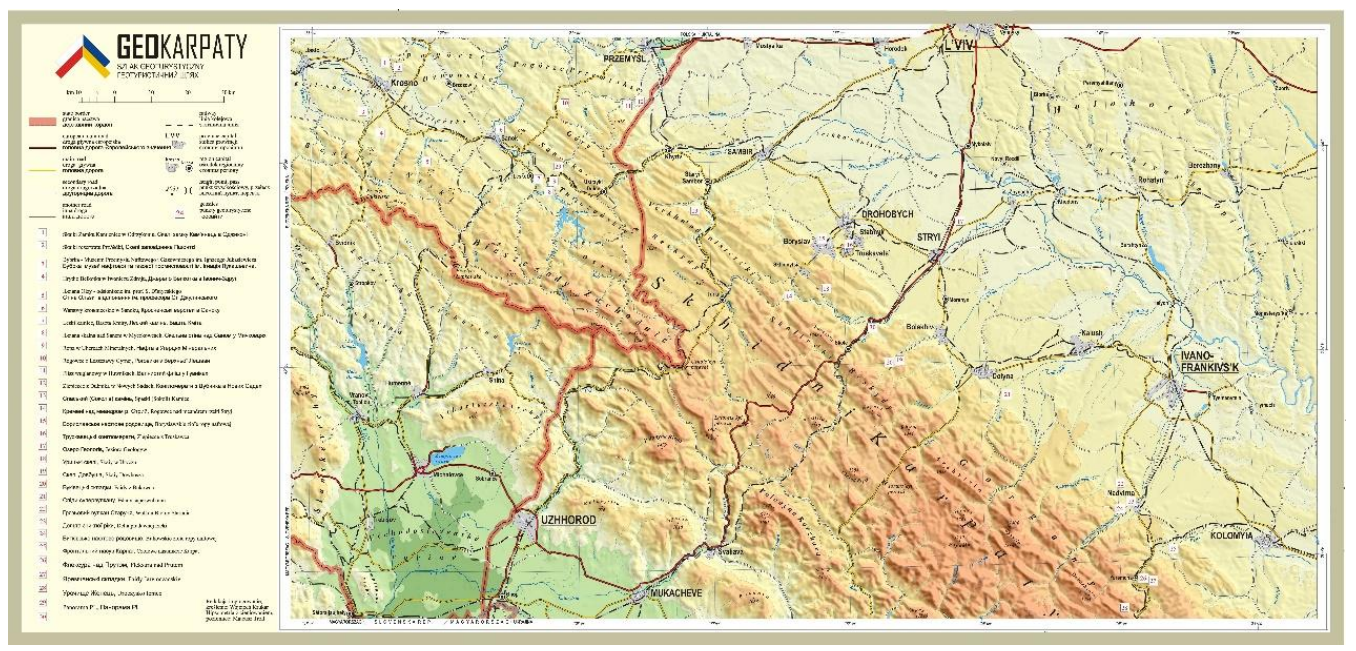

Fig. 1. Schematic map of the Geo-Karpaty geo-tourist route

Geomorphosites are distinguished based on the main scientific and educational criteria including cultural, aesthetic, economic and ecologic peculiarities [13, 16].

Analysis of publications. In the Polish Carpathians activities focused on preservation and tourism-aimed usage of geo-heritage is actively developed. The detailed inventory of main categories of geo-heritage i.e. natural monuments, reserves and documentation centres was done. They were assessed per the scientific and educational value $[10,15]$. Several tens of geological and geomorphological objects located within the Polish Carpathians were included into the national catalogue of geotourist objects [14].

For the Ukrainian Carpathians the last decade is characterised by an intense activity in studying, preserving and tourism-aimed use of geo-heritage. Geologists, geomorphologists, researchers and experts, representatives of the environmental institutions are actively engaged in this work. In particular, geological survey teams created passports on preserved geological objects in four Carpathian regions [2] and prepared an integrated characterisation of valuable geomorphological objects [4]. Recent years are marked by the energetic efforts to make geo-tourist potential capacity feasible and to popularize geo-educational potential of the region. The available geological tourist guidebooks [3, 5, 6, 7, 8], focused on educational and scientific groups, hold paramount significance.

\section{Geomorphosites as geo-tourist attractions}

The notion of geomorphosite, suggested by Italian researcher M. Panizo (2001), reflectes an integrated (scientific, cultural, aesthetic and tourist) assessment of geomorphological objects [16].

According to E. Reynard et al. [16] additional matters of geomorphosites include ecological values featuring the criteria of ecological impact and protectability from the outer affection; cultural values featuring the criteria of historical, artistic and religious importance; aesthetic values featuring the criteria of visibility, contrast, and spatial structuring; economic values featuring the criterion of their significance for production, including recreation.

Foreign researchers emphasize on certain distinctive features that distinguish 
objects of geomorphological heritage (geomorphosites) from other categories of geoheritage (geosites) [16]:

- many geomorphological objects show expressed aesthetic features. Owing to these qualities they are natural geopreserved monuments;

- these objects are of dynamic character caused by modern geomorphological processes. This distinguishes geomorphological guarded objects from other types of geoheritage (stratigraphic, lithological, paleontological), which are static ones;

- these objects are of various sizes. Objects of geomorphological heritage can be presented by both local units and complex forms and geomorphological landscapes.

To assess geotourist potential capacity of geomorphosites is possible through the approach proposed by V. M. Bruschi and A. Cendrero [11, 12]. All criteria in the named approach are obtained by synthesis from already existing techniques used to assess geo-tourist potential capacity and can be grouped into three main categories [12]: a) scientific value (intrinsic site quality): rarity, scientific importance, advantage to be used as a model to demonstrate processes, variety of elements, age, terrain type, combination with historical, archaeological, artistic heritage, association with other elements of nature, preservation status; $b$ ) potential for use: kinds of possible activities, observation conditions, accessibility, extent of use, proximity to service centres, socioeconomic situation in a region; c) possible threats and the need for protection: urban settlements in the vicinity, possible and potential threats, possibility to collect samples, harmony with modern planning.

The cross-border Geo-Karpaty geotourist route (Ukrainian and Polish parts) includes the following types of geomorphosites [1, 3, 7, 9]:

1) rocks - Rocks of the Kamieniec Castle in Odrzykon, rocks in the Przadki Reserve, Kamień Leski (Baszta Kmity) from the Polish side, Spaskyi (Sokoliv) Stone, the Urych Rocks, the Dovbush Rocks from the Ukrainian side;

2) parts of river valleys - meander of the Stryi river, Zhenets stow in the Ukrainian part of the route, the San River Valley in the Polish part;

3) fragments of landscape with contemporary manifestations of geomorphological processes - mud volcano Starunya in Ukraine;

4) anthropogenic landscapes - oil in Uherce Mineralne (oil manifestations in the Polish part of the route), the lake of Geologists (originated due to gas production) in the Ukrainian part of the route.

In this research main attention concentrates on rock geomorphosites. Their geotourism potential was rated by criteria of method of V. Bruschi and A. Cendrero [11, $12]$.

\section{Karpaty route}

The most prominent rock geomorphosites in the Polish part (Bieszczady) of GeoKarpaty geotourist route are rocks of the Kamieniec Castle in Odrzykon, rocks in the Przadki Reserve and Leski Stone (Kamień Leski, Baszta Kmity). Below we present their geo-tourist assessment in the scientific and educational perspective as well as solutions on how to use them for tourism.

Rocks of the Kamieniec Castle in Odrzykon (site 1) form western extension of the 
Przadki Reserve (Fig. 2). Scientific value: These sediments were deposited during the first stage when stream was losing its speed and have been preserved since then in channels curved in earlier sediments. The rock walls show erosive structures originated as the result of stream movement in older sediments. The rock object attractiveness is complemented with the castle remnants and well-provided informational and educational infrastructure of historical and cultural environment.

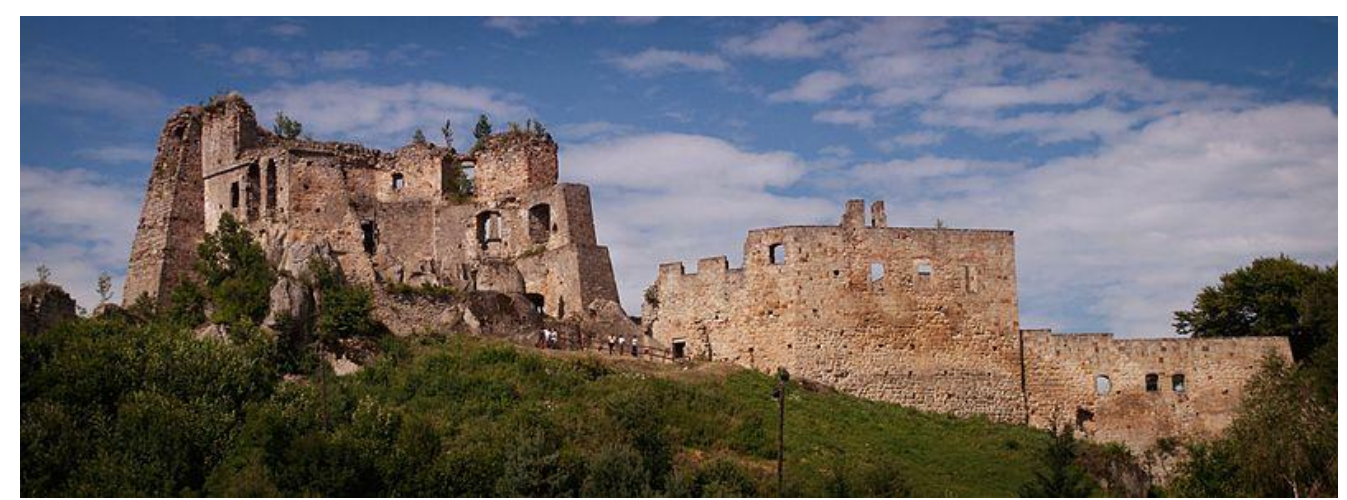

Fig. 2. Rocks of the Kamieniec Castle in Odrzykon (Photo [17])

Potential for using: it caused by high popularity of this object for regional excursions. It is the object of visiting in a number of regional and local tourist routes. Potential threats and protection necessity: for this object is characterized with excessive recreational capacity with devastation of soil and floral cover. There is a necessity of regulation of tourist flows.

The Przadki Reserve Rocks (site 2) form eastern exposures of Ciezkowice sandstones outcropped in the vicinity of the Kamieniec Castle (Fig. 3 and 4). Scientific value: They are composed of the so-called fluxoturbidites, i.e. Ciezkowice sandstones defined as the Early Eocene sediments of sludge underwater marine streams flowing down the continental slope.

The rocks shape is caused by the long-lasting exposure of sandstone layers to wind and water and temperature changes. The walls of rocks show diverse forms of weathering: 1) cellular structures - round holes separated by narrow ribs or larger irregular cavities; 2) depressions formed in places where rock was weakly cemented or contained clay formations; 3) vertical grooves, troughs formed because of draining rainwater. Potential for use: The Przadki Rock Complex is the most widely visited monument of the inanimate nature in the Bieszczady. It is equipped with information boards and a network of sightseeing paths. Possible threats and the need for protection: One of the problems detected at the geomorphosite is its excessive recreational and tourist load, which causes recreational digression of soil and vegetation cover as well as the development of erosive forms of micro-topographic units. There are several samples of mechanical and painted graffiti on the rock surfaces. For the most degraded sites we offer to equip wooden stairs and plankings for sightseeing places. 

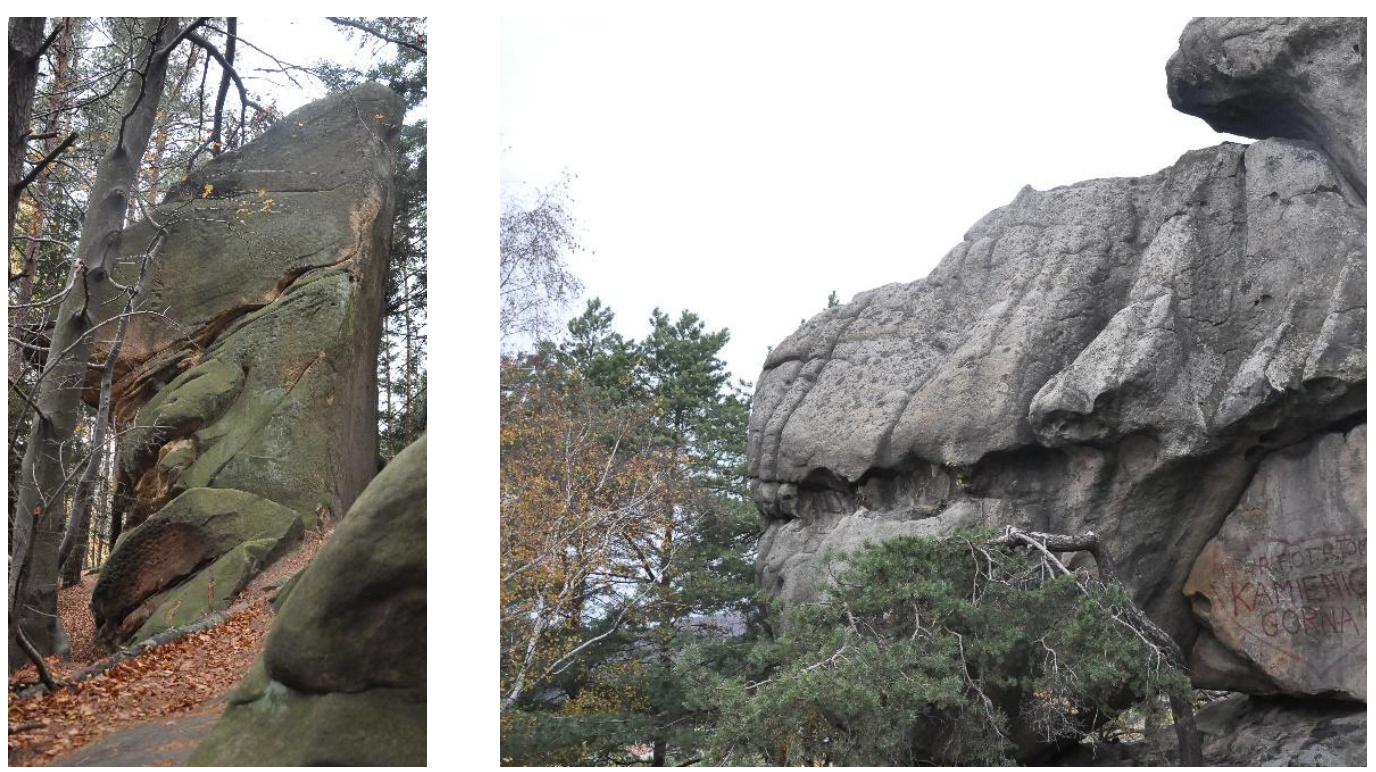

Fig. 3 and 4. Rock complex in the Przadki Natural Reserve (Photo A. Solecki)

Leski Stone (Baszta Kmity) (site 7) is a rocky ridge stretching for about 220 meters from northwest to southeast (Fig. 5 and 6). Scientific value: Original appearance of the rock is preserved only in its upper part, which looks like an eight-meter tower whose walls are formed by the steep slip joints. On the south-western wall one can see the signs of weathering: systems of depressions resembling honeycombs. The tower is surrounded by a deep quarry where stone was mined for centuries and used for nearby buildings such as castle, church and synagogue in Lesko. Stone taken from this place was also used to build fortress in Przemysl and regional railway infrastructure.
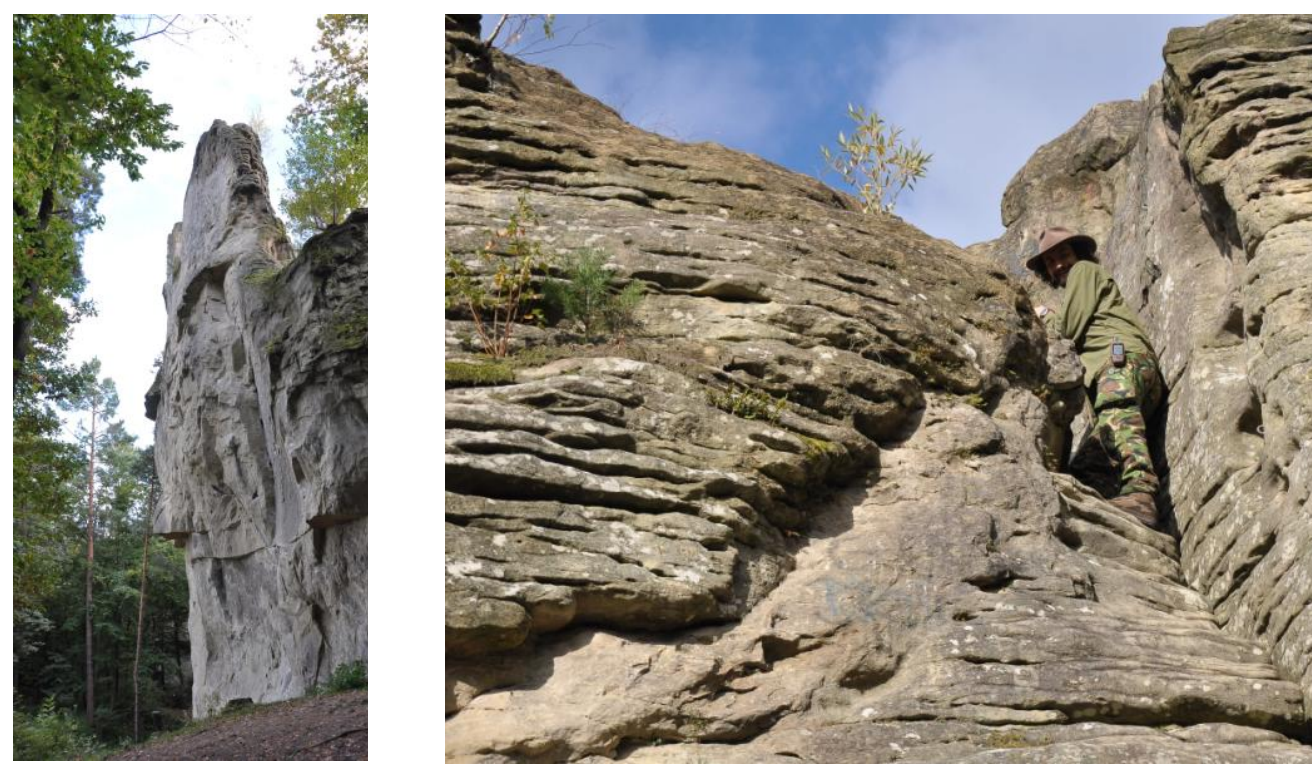

Fig. 5 and 6. Leski Stone (Baszta Kmity) (Photo A. Solecki) 
Potential for use: Leski Stone is an intensively visited tourist object. Here there is a parking lot and a sightseeing path. Leski Stone belongs to places visited by excursions groups, cyclists and autotourists. Possible threats and the need for protection: Recreational digression of soil and vegetation cover is observed. Various types of graffiti are visible on rock surfaces. There is necessity of arranging of didactic path (information stands, wooden stairs, plankings) taking into account environmental requirements.

\section{Geotourist potential of rock geomorphosites in the Ukrainian part of the Geo-Karpaty route}

Rock formations such as Spaskyi Stone, the Urych Rocks and the Dovbush Rocks were chosen as basic geomorphosites of Geo-Karpaty geotourist route in its Ukrainian part.

Spaskyi (Sokoliv) Stone (site 13) is a unique rock complex in the Upper Dniester Beskids (Fig. 7). Scientific value: As compared to other rock complexes (the Urych Rocks and the Dovbush Rocks) this one is distinguished by its older sandstones (approx. $100 \mathrm{Ma}$ ) of Spaska series and specific morphological structure. Rock formation is represented by three rocky monadnocks of tower or wall morphological type. The maximum height of the extreme western monadnock is 25 m. Rocks contain massive small and medium grained grey quartz sandstones with silicate cement. The thickness of sandstones is more than $10 \mathrm{~m}$. The walls of rocky monadnocks demonstrate various well expressed types of micro-topographic units such as alveolar weathering forms on the northern walls of rocks, hollows and niche.

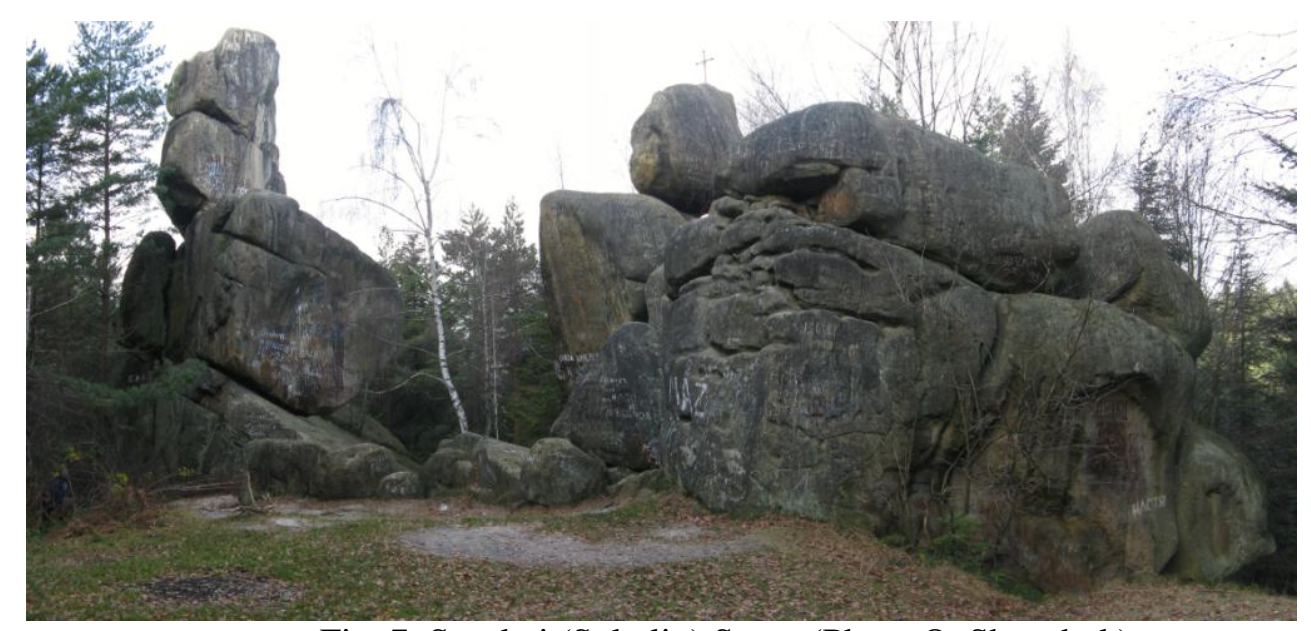

Fig. 7. Spaskyi (Sokoliv) Stone (Photo O. Shevchuk)

The local name of rocks is "Devil's Stone" and it reflects one of the legends about their origin, associated with the famous spiritual centre and monastery located in the village of Lavriv. According to the legend, the devil planned to destroy the sanctuary so he brought this stone here. Potential for use: According to legends king Danylo Halytskyi built a castle at this place that is why the tourist route "Along king Lev's paths" is marked up to Spaskyi Stone. Spaskyi Stone is a popular destination for excursions and recreation. Close to the rocks, besides informational and educational 
infrastructure of historical matter, recreational stops are arranged along the tourist route. Possible threats and the need for protection: Within the territory an express digression of soil and vegetation cover is observed, rocks are covered with various types of graffiti. The path requires environmental protections preparations - stairs at the most degraded slopes areas.

The Urych Rocks (site 18) is a unique natural and architectural complex located within the Oriv ridge in the Upper Dniester Beskydy (Fig. 8).

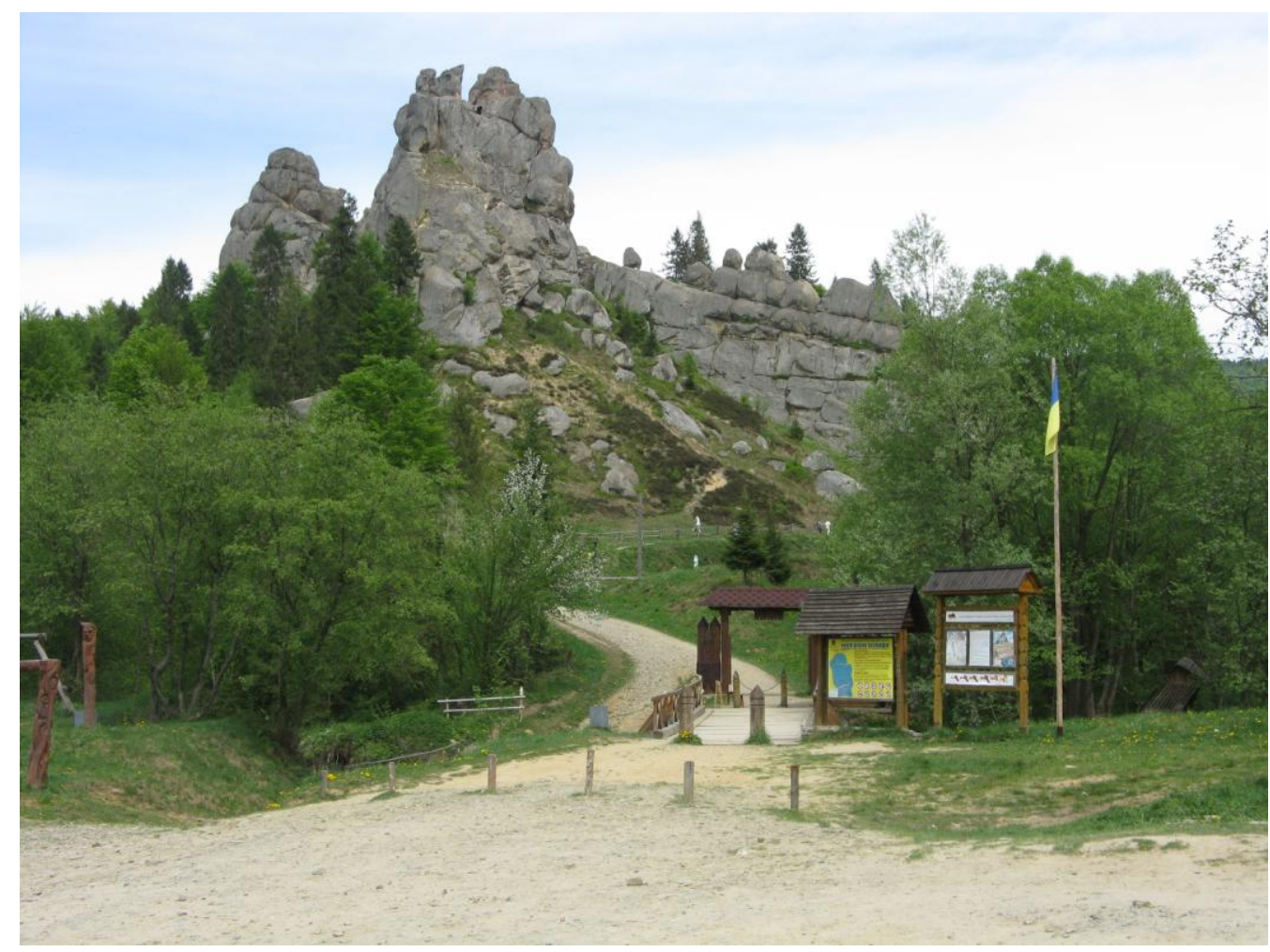

Fig. 8. Urych Rocks (Photo O. Shevchuk)

Scientific value: Under the morphological expression along with the historical and cultural significance, conditioned by the Tustan Old Rus' rock fortress, four rock formations are detected as follows: Kamin', Zholoby, Mala Skelia and Ostryi Kamin'. Their maximum height is $50 \mathrm{~m}$. All rocky monadnocks are composed of the Yamna series subvertical sandstones of various thickness. Rocks originated due to erosive processes when harder sandstones remained and softer argillites and siltstones were eroded. On the rock surfaces there is collar, cellular and arched weathering observed. Fissures (vertical and subhorizontal) often form an expressed block cleavages used to build the wooden fortress Tustan during the Medieval Ages. Several stages of the fortress construction are reflected by numerous holes carved in the rock surface. In most cases, they are located next to the bedding elements and tectonic fractures.

Potential for use: The site is extremely popular among sightseers (especially those coming from Morshyn, Truskavets and Skhidnytsia resorts). Facilities are presented by a checkpoint, informational and educational boards and marking signs, labelled paths, 
recreation stops and parking lots, catering facility stay open during the summer months. In the vicinity there is the Tustan museum and the chapel near the spring. Each year in August the popular festival of historical reconstruction "Tu stan!" is held here. Possible threats and the need for protection: in recent years have been taken measures to prevent recreational digression with building wooden flooring. Paths need an environmental protections arrangement to nearby separate rocks.

The Dovbush Rocks (site 19) is one of the largest rock complexes in the Skolivski Beskydy, located near the village of Bubnyshche (Fig. 9 and 10). Scientific value: Beyond the main formation, being the most popular place for visits, rocks extend south-west like a strip $200 \mathrm{~m}$ wide and up to $1 \mathrm{~km}$ long (Fig. 9 and 10). Tower, pole, composite wall with height reaching up to $80 \mathrm{~m}$ are the dominant morphological types. Rocks are composed of massive sandstones corresponding to the Yamna series, the Upper Paleocene (57 Ma).
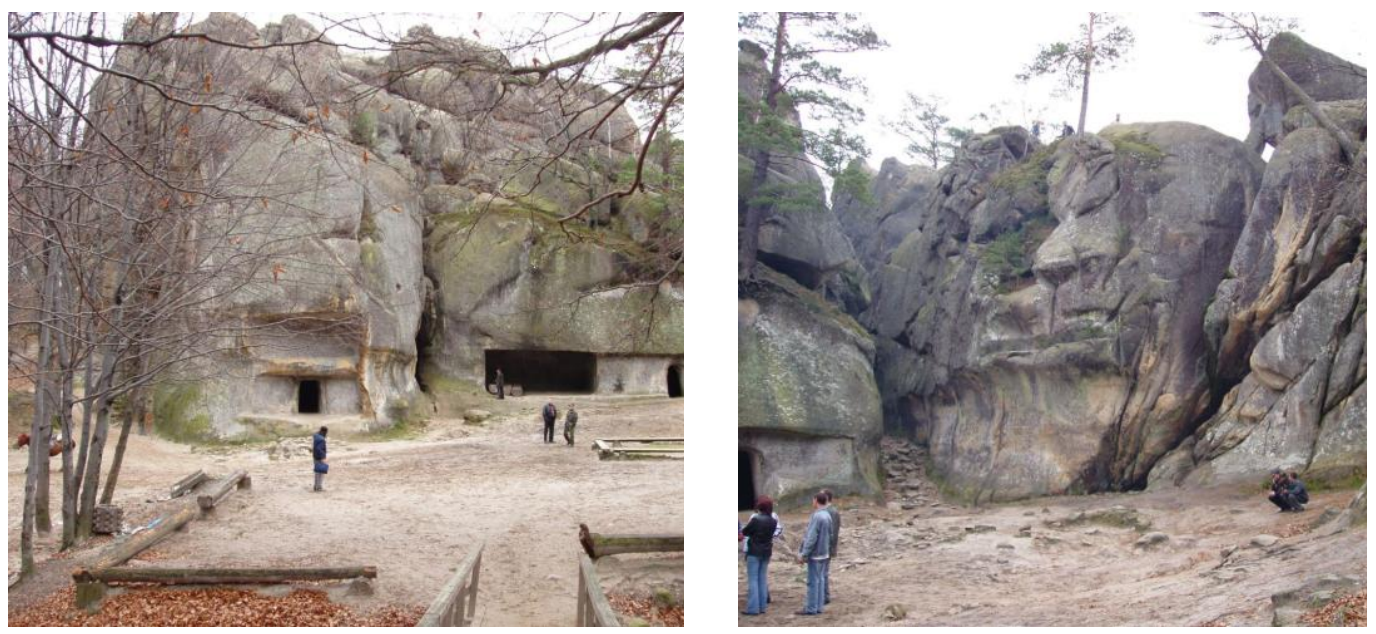

Fig. 9 and 10. Dovbush Rocks complex in the village of Bubnyshche (Photo Y. Zinko)

Here one can see a number sedimentary and tectonic phenomena. Forms of cellular weathering are very interesting. Within the main formation four artificial caves are found. Archaeologists suggest that in ancient times there existed a pagan sanctuary, and after spreading Christianity in the Carpathians a little Old Rus' monastery-skete was founded. Some rocks resemble animals or people. Scattered rocky monadnocks among hard Yamna sandstones originated due to both uneven cement composition in sandstone and various properties of mineral formations they are composed of.

Potential for use: The Dovbush Rocks is especially popular among sightseers coming from Morshyn, Truskavets and Skhidnytsia resorts, and are included into many tour itineraries. Competitions in rock climbing, bouldering and mountain cycling are regularly held here. Infrastructure is presented by informational and educational boards and marking signs, labelled paths and parking lots. Catering facilities stay open during the summer months. Tourists can experience other attractions such as horse riding, having photos with wild birds etc. Possible threats and the need for protection: Soil and vegetation cover within the complex territory is devastated because of intensive recreational and tourist load, rocks bear traces of several graffiti. For limitation the 
further degradation soil and floral cover it is necessary to restrict services of horseriding. For the tourists safety it is necessary to equip stairs for climbing to the top of Main massif and sightseeing grounds with a fence.

Conclusion. Geomorphosites, analysed as the objects of geomorphologicl heritage of Geo-Karpaty Ukrainian-Polish route, are represented with the attractive rocks and rock complexes. The majority of rock units are popular places for recreation and camping. Hotels and catering facilities are nearby the objects. They need informational and advertising support as well as arrangement of adequate infrastructure. By the virtue of international project "Geo-Karpaty" each of the analysed geomorphosites was equipped with informational boards and the description of these sites was included into the Ukrainian-Polish guidebook "Geo-Karpaty".

The assessment of possible threats for geomorphosites and the development of measures to minimize recreational load should be considered as a subject for further studies. Another arising issue of scientific, applied and programme character is justification of special infrastructure for geo-educational and geo-tourist aims for main types of geomorphosites.

\section{REFERENCES}

1. Бубняк I. Геотуристичні атракції транскордонного шляху «Гео-Карпати» (українська частина) / І. Бубняк, Ю. Зінько, М. Мальська, Л. Скакун, О. Яцожинський, А. Салєцкій - Вісник Львівського університету. Серія географ. - Вип. 43. - Ч. 2 - 2013. - С. 309-321.

2. Геологічні пам'ятки України: У 3 т. / В.П.Безвинний, С.В.Білецький, О.Б.Бобров та ін.; За ред. В. І. Калініна, Д. С. Гурського, І. В. Антакової. - К.: ДІА, 2006. - Т.1. - $320 \mathrm{c}$.

3. Геотуристичний путівник по шляху "Гео-Карпати" Кросно - Борислав Яремче : Монографія / [за ред. І. М. Бубняка і А. Т. Солєцького] - Кросно: Державна Вища Професійна Школа імені Станіслава Пігоня в Кросно, 2013. $-144 \mathrm{c}$.

4. Зінько Ю. Заповідні геоморфологічні об'єкти Українських Карпат: структура, особливості поширення та використання / Зінько Ю., Брусак В., Гнатюк Р., Кобзяк Р. // Проблеми геоморфології і палеогеографії Українських Карпат і прилеглих територій. - Львів, 2004. - С.260-281.

5. Лещух Р. Й. Геологічна практика на Поділлі і в Українських Карпатах: Навч.метод. Посібн. / Р. Й. Лещух, В. Г. Пащенко, Р. М. Смішко. - Львів: Видавничий центр ЛНУ імені Івана Франка, 2004. - 224 с.

6. Мончак Л. С. Геологічний путівник по Івано-Франківській області / Л. С. Мончак, О. Р. Стельмах, В. Р. Хомин. - Івано-Франківськ: Лілея-НВ, 2010. $240 \mathrm{c}$.

7. Навчальні матеріали для провідників по шляху Гео-Карпати (Кросно Борислав - Яремче) / [за ред. І. Бубняк, А. Солєцкі] - Кросно: Видавництво Ruthenus, 2013. $-80 \mathrm{c}$.

8. Путівник геологічних екскурсій: II геодинамічна школа для геологівзйомщиків України. - Львів; Яремча; Рахів; Берегове: ДП “Західукргеологія”, 2004. -35 c.

9. Скакун Л. Українсько-польський геотуристичний шлях «Гео-Карпати» / 
Л. Скакун, Ю. Зінько, А. Бучинська, Я. Внук, Р. Райхель - Вісник Львівського університету. Серія міжнародні відносини. - 2012. - Вип. 25. Ч. 2. - C. 269-273.

10. Alexandrowicz Z. Geoconservation in Poland for progresses of long-lasting development. - Przeglad Geologiczny. - Vol. 56. - nr 8/1, 2008. - p. 579-583.

11. Bruschi V. M. Direct and parametric methods for the assessment of geosites and geomorphosites / Viola Maria Bruschi, Antonio Cendrero // Geomorphosites [ed. by E. Reynard, P. Corata, G. Regolini-Bissig]. - München: Verlag Dr. Friedrich Pfeil, 2009. - P. 73-88.

12. Cendrero A. Geomorphology and environmental impact assessment: an introduction / A. Cendrero, M. Panizza. - Supplementi di Geografia Fisica Dinamica Quaternaria 3-3. - 1999. - Turin. - P. 17-26.

13. Geotourism / Edited by Ross K.Dowling and David Newsome. - Elsevier Ltd., 2006. $-260 \mathrm{~s}$.

14. Katalog obiektów geoturystycznych w obrębie pomników i rezerwatów przyrody nieożywionej / [Red. naukowy T. Słomka]. - Kraków: AGH Akademia GórniczoHutnicza, 2012. - $720 \mathrm{~s}$.

15. Ochrona georoznorodnosci w Polskich Karpatach / Pod. red. Alexandrowicz Z. Warszawa, 2000. - $141 \mathrm{~s}$.

16. Reynard E. Geomorphosites: definitions and characteristics / Geomorphosites / [ed. by E. Reynard, P. Corata, G. Regolini-Bissig]. - München : Verlag Dr. Friedrich Pfeil, 2009. - P. 9-20.

17. Ruiny zamku Kamieniec - https://commons.wikimedia.org/wiki/File:Odrzykon_podkarpackie_krosnienski_Wojasz\%C3\%B3wka_Ruiny_zamku_Kami eniec_XIV_A-263_z_20.09.1968_dz.jpg

\section{ГЕОТУРИСТИЧНИЙ ПОТЕНЦААЛ СКЕЛЬНИХ ГЕОМОРФОСАЙТІВ УКРАЇНСЬКО-ПОЛЬСЬКОГО ГЕОТУРИСТИЧНОГО ШЛЯХУ «ГЕО-КАРПАТИ»}

\footnotetext{
Юрій Зінько ${ }^{1}$, Марта Мальська ${ }^{1}$, Ігор Бубняк ${ }^{2}$, Роман Гнатюк $^{1}$, Леонід Скакун ${ }^{1}$, Анджей Солсцкій ${ }^{3}$

${ }^{1}$ Львівський національний університет імені Івана Франка, вул. Доротенка 41, Львів, 79000, Україна, e-mail: zinkoyuriy@gmail.com

${ }^{2}$ Lviv Polytechnic National University, вул. С. Бандери 12, Львів, 79013, Украӥна,

${ }^{3}$ Вроилавський університет, пл. Університетська 1, 50-137 Вроилав, Польща

У рамках Програми добросусідства Польщі-Білорусі-України у 2013-2015 роках реалізовано проект з розбудови транскордонного туристичного шляху «Гео-Карпати» в Українських і Польських Карпатах. Цей шлях протяжністю біля 700 км включає 28 геотуристичних об'єктів. Його атракційну основу склали цінні у науково-освітньому і ландшафтно-естетичному плані геологічні відслонення, форми рельєфу та прояви сучасних динамічних процесів. Значну групу об'єктів українсько-польського геотуристичного шляху склали геоморфосайти - об'єкти геоморфологічної спадщини (скелі, річкові долини, антропогенні форми, геоморфологічні процеси.

У представленому дослідженні здійснено геотуристичний аналіз скельних утворень шляху «Гео-Карпати»: Скелі замку Кам’янець в Оджиконі, Скелі резервату Пшондкі,
} 
Лєский камінь (Башта Кміта) з польської сторони, Спаський (Соколів) камінь, Урицькі скелі, Скелі Довбуша з української сторони. Він включав детальний опис їх геологічної будови i морфологічних особливостей, історико-культурної оцінки, сучасного туристичного використання та інфраструктурного забезпечення. Запропоновано пропозиції щодо збереження і охорони скельних геоморфосайтів шляху «Гео-Карпати» i перспективного їх використання у пізнавальному туризмі.

Ключові слова: геотуризм, шлях, «Гео-Карпати», скельні геотуристичні об’єкти, геоморфосайти, інфраструктура. 